\title{
The role of educators in education transformation and development of Buddhist students in the era of covid-19 pandemic
}

\section{Lamirin $1 *$}

${ }^{1}$ Buddhist Education, Bodhi Dharma Buddhist Collage, Medan, Indonesia

\section{ABSTRACT}

The outbreak of a new coronavirus disease 19 (covid-19) has caused global pandemic that lead to a dramatic changed of education system, including Buddhist education. During the covid-19 pandemic, Buddhist educators are required to made tireless efforts to maintain learning continuity. Besides, the educators also should be able to adapt new pedagogical concepts and modes of delivering their teaching. This research is carried out a literature study to explore the role of educators in the effort of education transformation and the development of Buddhist students in the covid-19 pandemic. It is found that those educators still face various kinds of obstacles that need to be solved, such as (1) lack of skill and knowledge to carry out the teaching and learning process properly in accordance with the situation of covid-19 pandemic situation; (2) the availability of Buddhist teaching-learning sources in Bahasa Indonesia; (3) frequent changes of the curriculum; and (4) low education budgets to conducted online teaching and learning process, particularly in the remote areas. The results of this study contribute practical insights for educators, especially Buddhist educators in maximizing their role to transform and develop Buddhist students in the covid-19 pandemic.

\section{ARTICLE INFO}

\section{Keywords: \\ Buddhist education; transformation; development; covid-19 pandemic}

\section{Article History:}

Received: June $17^{\text {th }}, 2021$

Revised: June 22nd, 2021

Accepted: June $23^{\text {rd }}, 2021$

Published: June 28 ${ }^{\text {th }}, 2021$

How to Cite in APA Style: Lamirin. (2021). The role of educators in education transformation and development of Buddhist students in the era of covid19 pandemic. Smaratungga: Journal of Education and Buddhist Studies, 1(1), 2939.

\section{Introduction}

Indonesia is referred to as a religious country. Pancasila emphasizes the religious characteristics of the Indonesian nation and considers it the base support of the nation, which is the one and only God. The teachings of various religions are welcomed in Indonesia, and Indonesian society mostly maintain their religious values. Religion is considered as the highest source of wisdom and the source of morality, morality and spiritual teachings that are beneficial to human life. In modern life, with the rapid development of technology, religious teachings are still needed to guide society towards a more harmonious order. Dhammananda (2005) points out:

"Without religious guidance, science threatens the world with destruction....Cooperation between science and religion is very much needed for needs and services of mankind. Religion without science is lame, while science without religion is blind."

\footnotetext{
*Corresponding author: lamirin@bodhidharma.ac.id Published by Center of Research and Publication of Smaratungga Buddhist College

This is an open access article under the CC BY-NC 4.0 (https://creativecommons.org/licenses/by-nc/4.0/)
} 
Education is the transmission of values, knowledge, skills, attitudes and behavior. Education in a broad sense is life itself (lifelong learning), namely the process of eliminating ignorance and maturation towards perfection. Lifelong education is absolutely necessary and must be realized throughout the whole life. For one's life to progress, education is the main tool that must be managed systematically and consistently based on different theoretical perspectives and practices from time to time according to the human environment. Education is human needs. Education is always changing, developing and improving along with the development of all areas of life. Changes and improvements in education include several influencing factors, such as the implementation of education in this field (teaching abilities and teacher's quality), quality of education, teaching materials, educational premises and infrastructure, as well as the quality of education management, including changes to more innovative teaching methods and strategies. These changes and improvements aim to improve the quality of education in Indonesia.

According to Moses (2012), education is a process of transferring knowledge systematically from one person to another according to the standards set by experts. This kind of knowledge transfer is expected to change attitudes, biological maturity, and personality maturity in formal and non-formal education. Teguh Triwiyanto (2014) explains that education is an effort to trick people into something so that they can provide procedural and informal education in the form of life expectancy on and off campus, try learning experiences. Optimizing personal skills so that they can quickly play a role in life (Triwiyanto, 2014).

In order to educate the nation's life, improving education is very important for the sustainable development of all aspects of human life. The national education system must always develop in accordance with the needs and developments at the local, national and global levels (Mulyasa, 2006).

In Indonesia, religious education is carried out from elementary school to high school. Religious education has the characters of formal and informal. Religious guidance is given according to your religious beliefs and is taught by religious teachers. Through early learning of religious teachings, students should absorb religious teachings and incorporate them into the social conditions of daily life, so that these ideals will be achieved.

Schools play an important role in improving human resources for the teaching and learning process. Hamalik (2011) believes that from a practical point of view, five variables play a role in the teaching process: learning objectives, subjects, teaching methods and methods, teachers, students, and logistics. These factors mutually influence the achievement of the goals of the educational process. To study Buddhist education, it requires the ability to observe and internalize any fact, concept or procedure that requires organized steps to present research material for Buddhist education.

Buddhist education is a systematic and continuous activity that aims to develop students' abilities in increasing their belief and dedication to Buddha, having noble character, and increasing spiritual potential in accordance with the teachings of Buddhism. The Buddhist education curriculum is based on competency standards and core competencies, reflecting the need for various 
competencies at the national level. It is expected that this standard can be the basis for the preparation of a Buddhist education curriculum that meets the needs of the region or school.

Buddhist education aims to turn students into people who believe and faith to the Buddha, have noble character and increase their spiritual potential. Noble morals include morals, character and morals, and are the embodiment of religious education. Increasing spiritual potential includes the introduction, understanding and cultivation of values, religious values, the application of religious values and the application of these values in individual or collective social life. The ultimate goal of increasing one's spiritual potential is to optimize one's possibilities.

More clearly, Buddhist education aims to enable students to master the following skills, such as to develop: (1) faith (saddhā) and piety (bhatti) in the Triratna, Bodhisattva and Mahasattva; (2) Indonesian people who have noble character through increasing the practice of morality (sīla), meditation (samādhi) and wisdom (paññā) in accordance with the Buddha's teaching (Buddhadharma); Indonesian people who understand, live, and practice/apply the Buddha's teachings contained in the Tipițaka/Tripitaka Scriptures, so that, they become responsible human beings in accordance with Dharma principles in daily life; and (4) understand Buddhism and the history of its development in Indonesia.

Recognizing the importance of Buddhist education, various efforts have been made to improve the quality of teaching Buddhism in schools, such as rearranging the curriculum and improving the quality and ability of Buddhist educators. Buddhists borrow from the library and complete reading books and so on. To improve learning outcomes, we have made further efforts. However, it can still be said that the achievement of learning outcomes of Buddhism in schools is usually far from expectations.

One of the main factors that determine the quality of Buddhist education learning is the teacher. The teacher will be the party who plays an important role in the curriculum so that learning objectives can be developed and achieved appropriately. The teacher's ability is the main factor in determining the direction of learning and the achievement of learning objectives. This is important, because if he/she makes mistakes in learning management, it will not only have impact towards the students failure, but also affect on failure of student lives. Living process. This is because the Buddhist education training is full of values that are not only sufficient to convey the text, but also need to be conveyed according to the context. In the Buddhist education learning process, various themes that are developed in the children's environment are used as the teaching materials so that the students can have right vision and provide response that is according to Buddha's teachings.

In addition, the challenge for Buddhist educators is to become one of the stakeholders of the implementation of the 2013 curriculum. As it is too urgent, we can often see that the implementation of the 2013 curriculum faces many challenges, especially the challenges of material distribution and evaluation. Teachers have the same difficulties in teaching Buddhism in Tangerang. In several conversations between Tangerang and Buddhist teachers, the author found that there are several difficulties that prevent teachers from implementing the 2013 curriculum, such as: Minimum number of manuals, detailed management and 
changes to the grading system for courses before 2013. The above are methods to find out difficulties faced by teachers in implementing the 2013 curriculum, especially for Buddhist educators.

Furthermore, we are currently experiencing different conditions compared to before. Since February 2020, Indonesia and the world have been shocked by the outbreak of the Covid-19 pandemic. In this pandemic, many aspects are also affected, including in the field of education. The field of education has learning difficulties and must be completed every day. Learning will continue through the Internet which is available today. Online learning or online training is one of the alternative methods that can be done during the Covid-19 pandemic. During this pandemic, the government issued a policy that allows the society to avoid crowds and crowded places, be it work, study, worship or other events. Everything is done at home to break the chain of the Covid virus. In the world of education, this situation is changing the way teacher teach and students. You need to change the direction from traditional to modern so that in the face of the Covid-19 pandemic in 2020 the learning process can continue (Kumparan.com).

Various forms of human activities in the past usually require comprehensive and significant changes in accordance with various regulations issued by the government to reduce its spread. this corona virus. At home, such as work, school, worship, etc. The public must comply with all sanitation rules and agreements established by the government and the World Health Organization (WHO). And have to live life on a new level of normal. This changes every aspect of a person's life.

The outbreak also had an impact on the education sector and created problems for Indonesian educational institutions. The government has decided to close schools and universities. Training products need to be reorganized and adapted to sanitation rules that prohibit people from gathering in crowded places. The government has also developed several guidelines to help combat the impact of the virus on learning and teaching. Face-to-face (regular) learning has been cancelled, and learning is carried out at home through distance learning and the use of online media (Arizona, Abidin, dan Rumansyah, 2020). This change in the training system was beyond everyone's expectations, and they had to start off unprepared.

From this writing, researcher tries to convey the latest and most current conditions regarding Buddhist education that occurred in Indonesia during the Covid-19 pandemic and solutions that can be applied in the world of education in Indonesia, especially in the field of Buddhist education. The researcher conducted various analyzes that made it possible to answer the formulation for the problems contained in this study and were able to provide solutions to the problems that occurred so that they could be used by teachers and students in schools in learning Buddhism. The aims of this research is that to find out the conditions of learning for Buddhist education and the obstacles experienced as one of the contents of religious education in Indonesia and provide solutions related to steps that can be applied as an effort to adapt and transform Buddhist education during the Covid19 Pandemic. 


\section{Method}

This research is a type of library research. The so-called library research, or commonly called library research, is a series of activities related to the methods of collecting library data, reading, writing, and processing research materials. The data sources are literature or various publications, including books, magazines, newspapers, personal archives, and others. For more details, the data sources of this research are divided into primary and secondary sources, which are: (1) the primary source are journals and articles with the subject of Buddhist education in the Covid 19 pandemic; and (2) the secondary sources are other books that explore the concept of experiential learning. Books as secondary sources are used as primary storage media. Reinforce the concept of education based on the experience of the original book. Additional data sources related to education, teachers, educational transformation, and other education related topics.

This study uses qualitative methods because the source of data and research in the library is in the form of word descriptions. The writing of this study examines the importance of information or empirical evidence in books, scientific or formal research reports, or other literature.

Data collection techniques are associated with data sources. Data collection technology is the technology used by researchers to collect and extract data from primary and secondary data sources. Because the data source is recorded data, the data collection method in this study uses documents.

Document comes from the term "document" which means a recording of past events, and can be in the form of text, images, or other works of commemoration. In other words, documents are monumental works, pictures, or works that contain certain ideas. Or just thoughts or ideas expressed in writing, pictures, or other works.

Therefore, the recording method is a method of searching for data about a thing or variable in the form of notes, transcripts, books, newspapers, magazines, inscriptions, meeting notes, legends, agendas, and others, to explore and express thoughts, ideas, or methods. Ideas in the form of writing or pictures or other works.

The researcher uses the method of collecting data through documents because this type of research is library research. Literary research is a source of primary or secondary empirical data sourced from books, documents, journals or other literary studies.

Data analysis techniques used in research literature can use the method of content analysis. The steps or procedures for content analysis according to Fraenkel and Wallen (2007) are as follows: (1) the researcher decides the specific objectives to be achieved; (2) define the terms that important to be described in detail; (3) Specify the unit to be analyzed; (4) find relevant data; (5) build rational or conceptual relationships to explain how data relates to objectives; (6) planning sampling; and (7) formulating category coding.

After the researcher has determined in as much detail as possible the aspects of the content to be researched, he needs to formulate relevant categories for research. 


\section{Findings}

\section{Conditions of learning Buddhist education and obstacles experienced as one of the contents of religious education in Indonesia during the covid-19 pandemic}

Today's religious education, especially Buddhist education, has a very basic and serious problem. Basically, it refers to the implementation process that is inconsistent with the process to be completed in education. Buddhist education was particularly restricted by religious teachers. Buddhist educators have relatively few students, but are ineffective in their teaching. In an educational institution, its existence is divided into several educational institutions that are relatively far apart, so this makes the quality of religious education unsatisfactory.

The Buddhist teacher will perform non-permanent tasks in his/her duties, he/she will always move from one school to another, so his routine duties will be similar to public transportation. On the other hand, Buddhist educators should behave the same as any other teacher in the learning process, and the same applies when it comes to obtaining happiness, such as certification.

Referring to the research conducted by Tri Amiro (2018), it is explained that the difficulties of current education personnel who are required to be able to adapt in complex conditions with the implementation of the 2013 curriculum, making it a seriousness that needs to be built by the government in building a caring space for the implementation of Buddhist education. The level of difficulty experienced by education staff, in this case is Buddhist educators for the 2013 Curriculum implementation process, is $58.10 \%$. While the difficulty level of Buddhist educators in implementing the 2013 Curriculum in the competency aspect of the curriculum is $61.06 \%$.

In terms of students, Buddhist education students do not necessarily receive educational services from Buddhist teachers, but from religious leaders or teachers who have never been educated in Buddhism. As for other obstacles in the introduction of Buddhist education, such as: B. Lack of support and advice, because the number of authors of books on Buddhist education is small. In 2013, the government's plan to buy books online and paper became part of its own assessment of Buddhist education. The availability of these resources should also be carefully evaluated based on the existing methods of distribution of the book and whether the book can reach remote communities without internet access or other restricted access rights. Due to the number of students and their unequal distribution, this matter has become a part of problem in the service for Buddhism education and from time to time during the educational process.

The current conditions force everyone to make changes, especially from conventional learning to adapting newest technologies. Of course this causes heavy feelings in teachers and students. Especially for teachers, where teachers are required to be creative and innovative in developing lesson plans. Expected innovations such as in terms of methods, media, and learning facilities so that they can still transfer their knowledge to students even though in all limitations. Teachers are also required to be able to adapt to various technologies and applications of learning media providers. Teachers are required to be technology 
literate and run various applications in order to keep the teaching and learning process going.

This of course causes physical and mental stress for teachers and students. Where they are forced to do something new in the teaching and learning process. For teachers and students, this is certainly very difficult. Especially for teachers, teachers need to mobilize their creativity and innovation ability in formulating curriculum plans. Expected innovations, such as innovations in methods, tools, and teaching aids, allowing it to transfer knowledge to learners without any limitations at all. Teachers must also be able to adapt to various technologies and applications of learning providers. Teachers must have technical knowledge and be able to run various applications to continue teaching. When teachers and students are forced to do something new in the teaching process, it will surely bring physical and psychological pressure for them.

Internet learning also brings some obstacles, so that it is difficult for them to carry out the teaching and learning process properly. One of them is network restrictions and internet access. Although internet connectivity in Indonesia still available in many areas, apart from the financial situations of students are still very concerning, therefore they do not have mobile phones or laptops to support being students where all activities are carried out online.

Research conducted by Siregar (2020) reveals that the current period is classified as difficult times for both teachers and students. Eight months before the end of the investigation, online learning took place. Many incidents occur because schools, parents, and governments do not have online learning infrastructure. This kind of online learning has caused many problems, especially the state (educational institutions, society and government) is not ready for the introduction of the education system. online. Challenges faced by online learning in Indonesia include: The uneven availability of Internet service infrastructure networks in Indonesia. Due to the relatively equal coverage of ISPs, students living on the island of Java are usually very lucky, but students living outside Java (especially eastern Indonesia) are in danger for accessibility of the Internet. The Ministry of Communications and Information Technology announced on its official website that out of 83,218 villages or roads in Indonesia, 70,670 areas are confirmed to be able to use the $4 \mathrm{G}$ network, and this number has entered the $3 \mathrm{~T}$ area. In addition to the uneven distribution of Internet infrastructure in Indonesia, online learning problems also occur in the mentality of students and teachers who are still not ready to adapt to conditions that force all activities to be online.

The online learning requires the support and participation of various parties so that they can stay along and comply with all conditions and infrastructure for students so that they can continue to participate in online learning activities. Learning solutions that can be applied during the Covid-19 pandemic are innovation and adaptation to various changes and existing technologies, creative thinking and the ability to work with students and parents. Everyone must strive to achieve a learning model that is appropriate to the situation and conditions of students. In this case, cooperation between teachers and students is needed. Students and their parents must achieve and achieve the goal of educational ability. 
Buddhist education must be rooted in the noble culture of Buddhism. This status should reassure parents that their children are part of a society that parents can be proud of. Then go to elementary school until students. Its contents include the application of Buddhist values, knowledge and skills, as well as the application of various teaching methods and models that emphasize student-centered learning, discipline, and the ability to keep up with the developments of the era (Haryanto, 2017).

In Buddhist education section and character evaluation, it is stated that the evaluation method and form of evaluation are actually very different from the previous courses, paying more attention to the evaluation process, and the accumulation is part of the curriculum and portfolio format. Evaluation before students can actually perform or analyze performances based on the purpose and nature of Buddha's teachings, the evaluation model prioritizes mechanisms over evidence of test results.

The things that become obstacles, of course, need an improvement that is immediately carried out by various parties. According to Lycona's explanation, there are at least four levels of moral, namely education, thought, emotion and behavior. As one of the agents of character education in Indonesia, Megawangi noted nine pillars of character education, namely: (1) love for God and truth; (2) responsibility, discipline and independence; (3) trust and honesty; (4) respect and courtesy; (5) love, care, cooperation; (6) independent, creative, hardworking, and never give up; (7) fair behavior; (8) hospitality and humility; (9) tolerance, peace and unity.

\section{Steps that can be applied as an effort to adapt and transform Buddhist education during the covid-19 pandemic}

To carry out education characterized by Buddhism, various methods are needed that are in accordance with Buddhist religious activities. To support knowledge of Buddhism, the support of books on Buddhism is very important, both Buddhist Education books package and other supporting books. Methods like this should be implemented as soon as possible.

Homeschool education linked to Covid-19. In the past, courses were held in classrooms. However, when the pandemic broke out, face-to-face learning which has become a tradition/culture of the Indonesian people shifted from conventional learning to technology-based online learning (Sudarsana et al., 2020). Teachers must be able to ensure that students continue to study while studying at home, even in different locations. This online learning system can be implemented through WhatsApp Groups (WAG), Telegram, Zoom Apps and other online services.

This is closely related to the application of the learning model. The learning model is defined as a picture/pattern used during the implementation of the learning that will take place (Amini, Setiawan, Yanti, and Ningsih, 2019). Another opinion says that the learning model is an essay about a systematic procedure to gain learning experiences in achieving certain goals (Al-Tabany, 2017 ). In this regard, Permendikbud Number 65 of 2013 explains the Standards Process for Primary and Secondary Education that: first, to achieve the learning process as stipulated in the 2013 curriculum, it is necessary to apply a scientific approach and 
adopt a thematic learning model, second, integrated thematic both between lessons. or application in subjects of discovery/inquiry-based learning, and third, teachers encourage students to produce creations.

In addition, there are steps expressed by Phenjaya (2018) regarding the right learning model to be carried out for Buddhist students. Learning Buddhism requires a student-friendly learning model, such as the Think Pair Share (TPS) collaborative learning model, so that students do not get bored easily with learning activities. Think Pair Share (TPS) cooperative learning model gives students the opportunity to work alone and collaborate with others. Buddhist education is specifically designed for teaching that is able to adapt to surrounding environmental conditions.

\section{Discussion}

Learning to play an important role is one of the most important goals of this practice. This is because the Buddhism curriculum can train students to increase beliefs and devotion to the Buddha, have noble character and increase spiritual potential based on Buddhist teachings. Studying Buddhism requires observing and internalizing facts, concepts or procedures. This requires organized steps to present material for studying Buddhism.

This condition was created because the teaching method used by the teacher still often uses the lecture method, although sometimes the teacher also modifies it with other methods, but the lecture method tends to be dominant in delivering the subject matter. As in the research conducted by Kaad (2018), the learning styles of students at SMP Negeri 2 Pekanbaru in studying Buddhism tend to focus on the teacher, if the teacher orders them to do the work, the students rush to work, but if the teacher does not give anything then the students they will be busy by themselves and even leave the class, when asked about Buddhist education materials, many of them do not know because they study with the system when there are assignments, so the value of Buddhist lessons is very different from the value of other lessons. teachers still rarely give assignments that use media images, videos and so on. The results achieved are still not optimal and need to be updated.

This kind of online learning method is not new, because this kind of exercise has been used in several countries, especially developed countries. The unit-level learning process in primary and secondary schools is not yet popular and requires careful preparation to succeed. Teachers need to find interesting ways of learning by providing students with interesting learning materials to enable students during this coronavirus pandemic and not to feel bored and anxious.

During this pandemic, some interesting forms of online learning that teachers can use are, such as: (1) turns games into interesting learning materials based on the material; (2) shoots interesting videos or create self-concept teaching videos to make students feel like the teacher is teaching face to face; (3) use interesting multimedia images so that students don't get bored with homework; and (4) describes what the students have learned after watching the movie along with the tutorials. 


\section{Conclusion}

The study of Buddhism in Indonesia still encounters various obstacles faced in Indonesia. The process of learning and its supporting components require various kinds of improvements that need to be made. Especially in the current conditions, where the Covid-19 pandemic forces the entire education sector to adapt to learning from home. Basically, it refers to the implementation process that is inconsistent with the process to be completed in education. Buddhist education is particularly restricted by religious teachers. Buddhist masters have relatively few students, but are ineffective in their teaching.

From this, the author can suggest that there needs to be attention from various parties for the development of Buddhist education, especially in pandemic conditions like this. A strong commitment is needed in realizing something tangible in ensuring that the conditions of Buddhist education continue to exist and are able to increase the interest of Buddhist students in all learning conditions.

\section{Acknowledgements}

Gratitude and acknowledgement go to all Buddhist educators and students who were willingly to be the participants in this research.

\section{References}

Amiro, Tri. (2018). Identifikasi kesulitan guru pendidikan agama buddha dalam mengimplementasikan kurikulum 2013 di Tangerang dan DKI Jakarta. Jurnal Vijjacariya, 5(2), 113-28.

Al-Tabany, Trianto, I., B. (2014). Mendesain Model Pembelajaran Inovatif, Progresif dan Kontekstual. Jakarta: Prenada Media Group

Amini, R., Setiawan, B., Fitria, Y., \& Ningsih, Y. (2019). The difference of students learning outcomes using the project-based learning and problem-based learning model in terms of self-efficacy. Journal of Physics: Conference Series, 1-6. doi: 10.1088/1742-6596/1387/1/012082.

Arizona, K., Abidin, Z., \& Rumansyah, R. (2020). Pembelajaran online berbasis proyek salah satu solusi kegiatan belajar mengajar di tengah pandemi covid19. Jurnal Ilmiah Profesi Pendidikan, 5(1), 64-70. doi: 10.29303/jipp.v5i1.111.

Dhammananda, S. (2005). Keyakinan Umat Buddha. Jakarta: Karaniya.

E. Mulyasa. 2006. Kurikulum yang di sempurnakan. Bandung: PT Remaja Rosdakarya.

Hamalik, O. (2011). Proses Belajar Mengajar. Jakarta: Bumi Aksara.

Haryanto. (2017). Kajian implementasi pembelajaran berbasis E-learning dengan pendekatan Unified Theory of Acceptance and Use of Technology (UTAUT). Jurnal Khatulistiwa Informatika, 5(1), 14-20. doi: 10.31294/jki.v5i1.2270.

Kaad. (2018). Meningkatkan minat dan motivasi belajar siswa dalam mengungkap sejarah penyiaran agama Buddha dengan media interaktif dalam pembelajaran agama Buddha siswa kelas VII SMP Negeri 2 Pekanbaru. Jurnal PAJAR (Pendidikan dan Pengajaran), 2(6), 1050-1056. doi: 10.33578/pjr.v2i6.6550. 
Kumparan.com. Imbas Pandemi Virus Corona bagi Dunia Pendidikan Indonesia dan Global, 25 Maret 2020, 7:43 (April 22nd, 2021). Available: https://kumparan.com/kumparansains/imbas-pandemi-virus-corona-bagidunia-pendidikan-indonesia-dan-global-1t5YVXRYAbo.

Moses, M. (2021). Analisis pengaruh Pendidikan, pelatihan, dan pengalaman kerja terhadap produktivitas kerja pegawai dinas pertambangan dan energi provinsi Papua. Media Riset Bisnis \& Manajemen, 12(1), 18-36. Retrieved from: https://trijurnal.lemlit.trisakti.ac.id/mrbm/article/view/1103/983.

Phenjaya, E., W. (2018). Upaya peningkatan hasil belajar pendidikan agama Buddha menggunakan model pembelajaran Kooperatif Tipe Think Pair Share siswa middle years programme di Medan Independent School. Jurnal Prointegrita, 2(348), 100-108. Retrieved from: http://jurnal.darmaagung.ac.id/index.php/jurnalprointegrita/article/view/9 9.

Pohan, A., E. (2020). Konsep Pembelajaran Daring Berbasis Pendekatan Ilmiah. Jawa Tengah: CV Sarnu Untung.

Sudarsana et al., (2020). COVID-19: Perspektif Pendidikan. Medan: Yayasan Kita Menulis.

Siregar, H., D., P. (2020). Dilema pembelajaran online: antara efektivitas dan tantangan. Jurnal Mimbar Agama Budaya, 37(2), 57-63. doi: 10.15408/mimbar.v37i2.18918.

Triwiyanto, T. 2014. Pengantar Pendidikan. Jakarta: PT. Bumi Aksara. 